\title{
Spontaneous Not Rapid: Utopian and Anti-Utopian Conflict in EgyptianUrbanism - Case Study: Abu-Simbel, Sheikh-Zuweid, and Kharja Oasis.
}

\author{
Alaa Abdelhamid Elmanzlawi ${ }^{\mathrm{a}}{ }^{,}$, Hadir Youssef Helal ${ }^{\mathrm{b}}$ \\ a Lecturer in Department of ARCHITECTURE, Faculty of Fine Arts, Mansoura \\ University, Mansoura 35511, Egypt \\ b Assistant lecturer in Department of Architectural Engineering, Misr Higher \\ Institutefor Engineering \& Technology (MET), Mansoura 35511, Egypt
}

\begin{abstract}
Spontaneous cities are not fully recognized by concerned authorities in Egypt. However, spontaneous cities need to expand quickly in Egypt, and they are addressed regularly in a manner that would ensure sustainability. Also, there is a need to strengthen further studies that should be conducted on spontaneous cities' common characteristics as utopian cities. This paper seeks to investigate what spontaneous cities are? It also investigates spontaneous cities' role in introducing inspiring plans for renovating the new Egyptian cities, to be liveable cities for a better future. This paper adopts a descriptive-analytic methodology in assessing the feasibility of spontaneous cities in several phases, including focusing on studying examples of Egyptian spontaneous cities, namely Abu-Simbel, Sheikh-Zuweid, and Kharja Oasis. The study ends with the need to consider rapid urbanization as a goal for spontaneous cities' residents. Spontaneous cities' residents can do even more by retaining social connections, which support human experience of urban growth for their sustainability. The importance of this study is represented in giving certain hints to find a way to avoid the demographic changes that make Egyptian cities antiutopian and discourage utopian urbanization.
\end{abstract}

\section{KEYWORDS:}

Anti-Utopia; Spontaneous City; Utopia; Dystopia; Urban Design; Ideal City 


\section{INTRODUCTION}

Jane Jacobs thought about what makes city an interesting place to be and she said that it is mainly about the people: "cities have the capability of providing something for everybody, only because, and only when, they are created by everybody" (Jacobs J. , 1992). Unlike central cities, many spontaneous settlements in Egypt are not often recognized by the concerned authorities or urban institutions. These settlements should be well-invested in the future as they are considered a nucleolus for ideal cities. This study focuses on demonstrating the planning philosophy of spontaneous settlements, which contributes to planning utopian urban areas as a target to achieve a perfect community. Therefore, this study intends to apply this philosophy to change and enhance the real situation of Egyptian spontaneous cities by means of understanding the ideas of utopia, dystopia, and anti-utopia. In utopia, the flawless picture is clear, while in dystopia there is no system and otherwise anti-utopia may succeed with certain terms or else ultimately fails. So, the most successful city would thus achieve self-respect and the world`s most estimation in the systemic and human domain.

In Egypt's spontaneous urban reality, there are three main concerns, which are the "realization" of urban life, the prevalence of intellectual illiteracy, ignorance, or lack of information particularly among individuals, managers, and experts and finally the absence of human rights understanding. The adverse effect on spontaneous urban settlements can be avoided by two factors: first, human characteristics and unique features such as buildings and network motions; second, the power of human communication as human beings are the origins of life as well as the basis of the basis of security in the city; that's why both factors need to be achieved together, (See Figure 1).

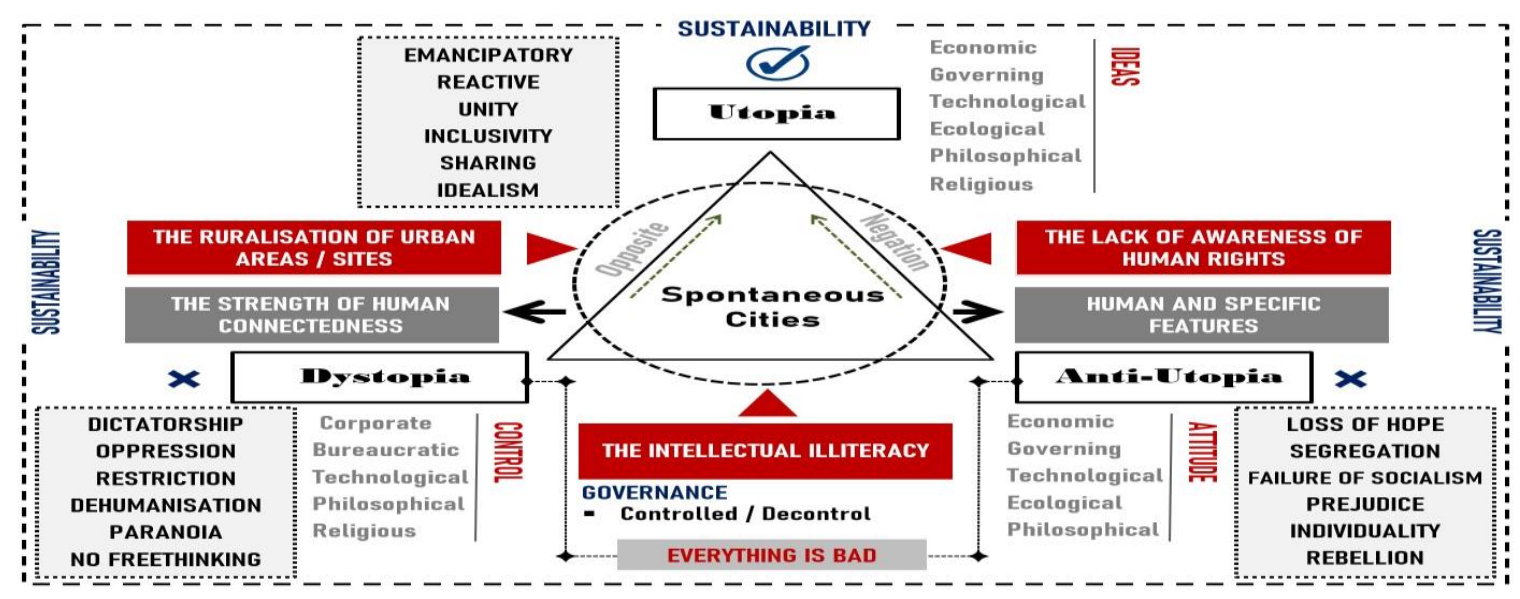

Fig. 1 - The Concepts of Utopia, Dystopia, and Anti-Utopia to Improve

the Status Quo inSpontaneous Cities - Source:

Researchers, 2020 
This paper attempts to explain how the significance of Egyptian spontaneous settlements or places can be dealt with in the light of current urban status. This can be achieved through considering them as a form of contemporary legal planning for Egypt's urban environment, especially in urban and rural areas that need constant nurturing, protection, or special services, as well as focusing on a profound understanding of the ideals of each society`s culture to help authorities and citizens together to work in and belong to this form of settlements to enhance their livelihoods.

- RESEARCH MAIN QUESTION: What is the role of SPONTANEOUS CITIES in introducing inspiring plans for renovating the new Egyptian cities, to be liveable cities for a better future?

RESEARCH HYPOTHESIS: Following An understanding of the SPONTANEOUS character of the city can change behaviour of authorities and citizens together to stop further INHUMAN settlements, which if left un-dealt with will considered a nucleolus for slum growth. So, these spontaneous cities should be well-invested in the future as they are considered A nucleolus for ideal cities.

- RESEARCH OBJECTIVE: The purpose of this research is to overcome the partial and reductive vision about Spontaneous cities as a "Slum", "Shanty Town", "Informal", and "Uncontrolled Urban Settlement", and make it reconsider as means of extraordinary resource, either cultural or ethno-anthropological.

- $\quad$ RESEARCH AIMS: This study aims on Exploring and Demonstrating the planning philosophy of SPONTANEOUS CITIES, and Evaluate its effectiveness in being integrated in the contemporary forms of legal planning for Egypt`s urban environment... Especially in SPONTANEOUS CITIES ON EGYPT OUTSKIRTS, namely Abu-Simbel, Sheikh-Zuweid, and Kharja Oasis as a target to achieve a perfect community belong to this form of cities to enhance their livelihoods Through an exploration of the relevance as well as the significance of the similarity and the difference between spontaneous cities and the ideas of Utopia, Dystopia, and Anti-utopia. 


\section{SPONTANEOUS CITY QUESTS: CONCEPTUAL FRAMEWORK AND LITERATURE REVIEW}

\subsection{An Overview}

The Wiktionary (Wiktionary, 2020) notes that the word "spontaneous" is a Latin term meaning "freely" or "voluntary". The word comes from the Latin word "sponte." That definition remains common. Yet, the word has a new definition i.e., "no planning" (Levinson, 2017). While the term sounds unusual, it is also synonymous to rapid settlements. Spontaneous urban characteristics generally have unplanned, unpretentious, and seemingly disorderly configurations of buildings that are marked by high density, poor overcrowded drainage networks, violence, hostility and dysfunctional. (Ekandem, Daudu, Lamidi, Ayegba, \& Adekunle , 2014). In the past, a Spontaneous City used to be highly criticized for economic and social reasons as the phenomenon was highly connected to mindsets. Spontaneous City's global vision varies today as it is referred to as a quite affluent urban form. This paper aims to define and validate the conception of "spontaneous cities" in addition to determining its characteristics and effective factors. Also, this paper defines the basics and considerations that should be followed to attain a clear-cut, real and malleable theoretical framework for using spontaneous cities as a model that responds to the social and economic needs of its local residents.

\subsection{The Concept of Spontaneous City}

Spontaneous cities' historical roots date back to the ancient times when God created and ordered people to reconstruct the land in accordance with the available natural resources. The spontaneous city is based on the premise that the community is designed by and for its inhabitants, where that was clearly explained by architects and urban planners in the East and West in their scientific works. Spontaneous cities are categorized according to numerous concepts; traditional cities, popular cities, national cities, eco-cities and human cities. From the views of the majority, the stereotyping of a 'spontaneous city' is known as chaotic neighborhoods that should either be restored or entirely redesigned and/or reshaped to suit the contemporary city's broader view. Spontaneities in urban settlements, on the other hand, are not necessarily considered to be infamous. Sometimes such settlements are highly tourist destinations in the city and areas where the city identity, history, culture, and local heritage can be felt (Cullen, 2015). 


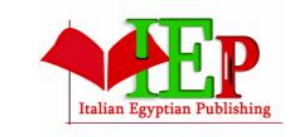

ISSN: $2785-9673$
INTERNATIONAL JOURNAL OF

ARCHITECTURAL ENGINEERING AND URBAN

RESEARCH

VOLUME 4, ISSUE 1, 2021, $18-40$.

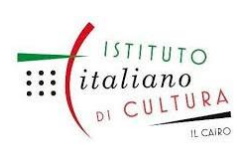

www.egyptfuture.org/ojs/

Spontaneous cities are described in the Urban Geography Glossary (Urban Geography Glossary, 2021) as the outer spread of the built-up areas caused by the extension and the insufficient of basic services. Furthermore, it is described by Wikipedia (2010) as the extension on the urban outskirts of a city and its suburbs. We conclude, ultimately, that a spontaneous city is the "city where its physical output reflects the fact of time and space, etc...' Moreover, it constitutes the concept of collaborative artistic action based on local community activities and craft skills produced in conjunction with its local residents' needs. Spontaneous cities can be analysed according to three essential components: (1) the environmental component, (2) the ideological component, and (3) the social and political components (See Figure 2).

SPONTANEOUS CITY COMPONENTS
The Spontaneous City Belonging

Fig. 2 - Spontaneous City Components - Source: Researchers, 2020 


\subsection{Characteristic of a Spontaneous City}

From (Figure 3) the features in a spontaneous city can be inferred.

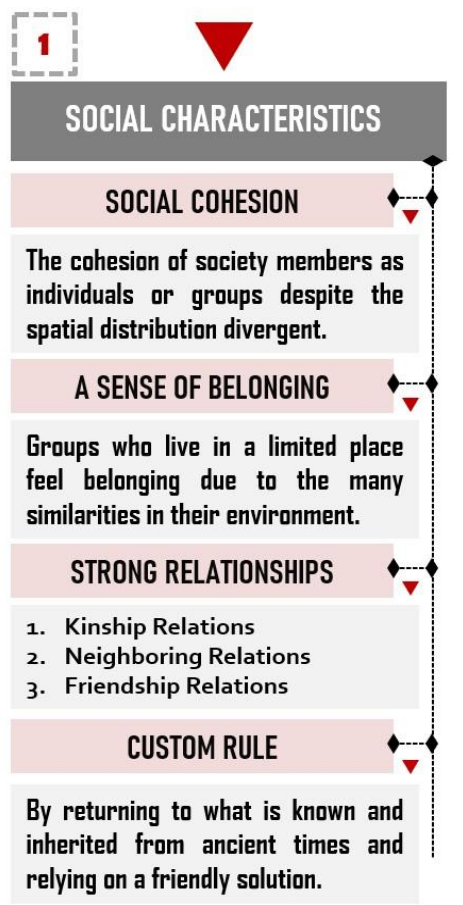

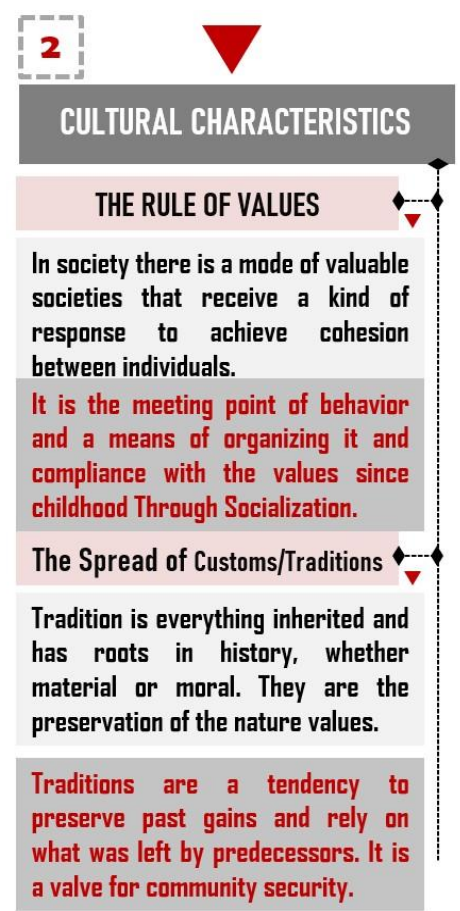

\section{Fig. 3 - Characteristic of a Spontaneous City - Source: Researchers, 2020}

\subsection{Principles of a Spontaneous City}

Pursuant to the study, the basic and guiding principles underlying the spontaneous city approach with respect to sustainable planning are: 1) Flexibility and participation: a significant aspect of the a spontaneous style is the flexible and appropriate nature, which responds to needs. Urbanism, which allows flexibility to select, and readily responds to variable needs and desires of the beneficiary population, is also sustainable over time (Kazimee, 2008). 2) A sense of place: the spontaneous conventional urbanization considers cities to be a living urban structure, and they are shaped based on social and cultural needs. The comprehensive system of these urban areas produces an area that respects the local identity and delivers convenience and enjoyment (Dabaieh, 2014). 3) Self-sufficiency: the use of local technology and resources should be included in contemporary planning and construction approaches. Local materials and simple processing methods are ideal for a large variety of individuals, who can support their daily needs. Also, preserving 
and adapting existing goods even to new uses, i.e. the reuse and recycle of materials and goods. 4) Complementarity with the environment: spontaneous urban planning is a search of an integrative human/environmental partnership. The knowledge of the site's microclimate and topographic characteristics will improve certain natural energy cycles and reduce the consumption of resources. A special local climate is created by the effect of vegetation on the interior treatments of spaces, and taking advantage of steering buildings by solar exposure and wind. Also, using materials, surface texture and colours of the spaces structure limit the use of energy (Abdelllatif, 2003).

\subsection{Factors Responsible for Growth of a Spontaneous City}

The spontaneity of the settlements in urban areas is triggered by a variety of factors, including:

- The exponential population growth constantly places pressure on current residential facilities.

- $\quad$ Failure of housing infrastructure to meet housing needs adequately that has successfully compensated the bulk of low-income householders,

- $\quad$ Cities have endless socio-economic opportunities, particularly when it comes to the development of land. The activity of economic powers to provide land for commercial construction in the city center promotes the purchase of land for residential construction in the suburb of the city,

- $\quad$ The government's failure to successfully manage land property in some cities; therefore, the reluctance of land to citizens is still already growing, without the planner authority being appealed to for planning authorization,

- The inefficiency of the mechanism or policy of the planning bodies in removing such a sprawl that lacks political commitment to enforce control measures for growth,

- Community rehabilitation projects in metropolitan communities without a scheduled relocation have contributed to a systematic progressive enlargement to provide housing self-help. 


\subsection{Spontaneous City as a Quest for the Ideal City in Egyptian cities}

The main reasons for living in spontaneous cities are that some residents now face the risk of being forced out of their precarious living quarters and jobs. Hence, they lack a sense of identity and cannot adapt or find the comfort they need within cities that are well-planned by the government, in addition to justice, freedom, prosperity, stability and dignity.

Consequently, most of them feel alienated; and thus people`s choices and opinions diminish. Therefore, here is the question; "what is the current state of utopia, dystopia and/or anti-utopia with the spontaneous Egyptian Cities?" As seen in table 1 , the city and people living there have much to do with these concepts. (Hayes, Kumar, \& Papadopoulos , 1987) (Utopia in Dark Times: Optimism/ Pessimism and Utopia/Dystopia, 2003) (Clays, 2013) (SARGENT, 1994) (Sargent, 2010) (Atkinson, 2005) (Ellin, 1999) (Blackshaw, 2014).

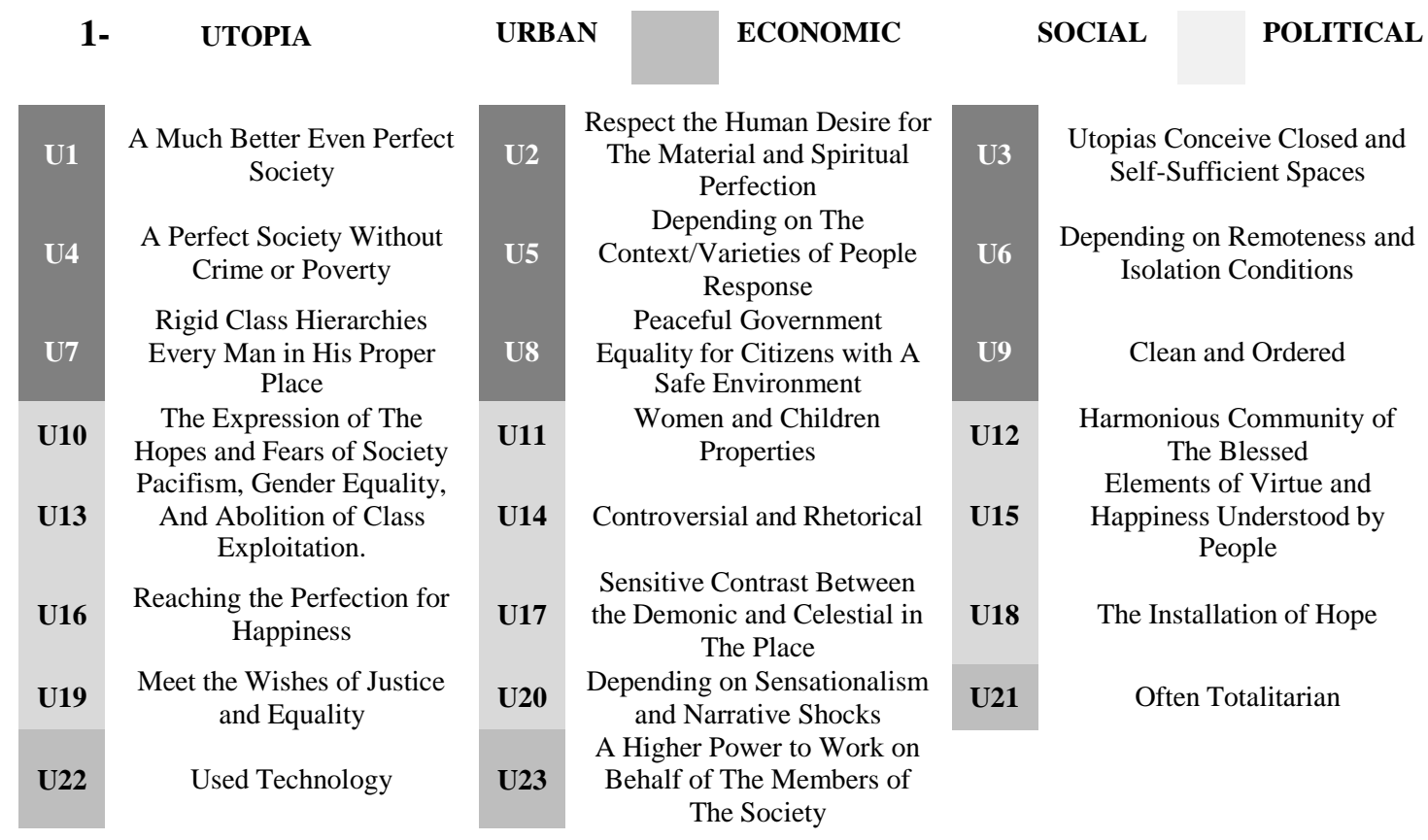

Table (1): The Composite Notion of Utopia, Anti-utopia, and Dystopia 
It can be concluded that the idea of anti-utopians is an intermediate phase between utopians and dystopian communities. The types and relationships resulting from the change of factors, conditions, and policies, followed in each direction, were analyses, and illustrated in (Figure 4).
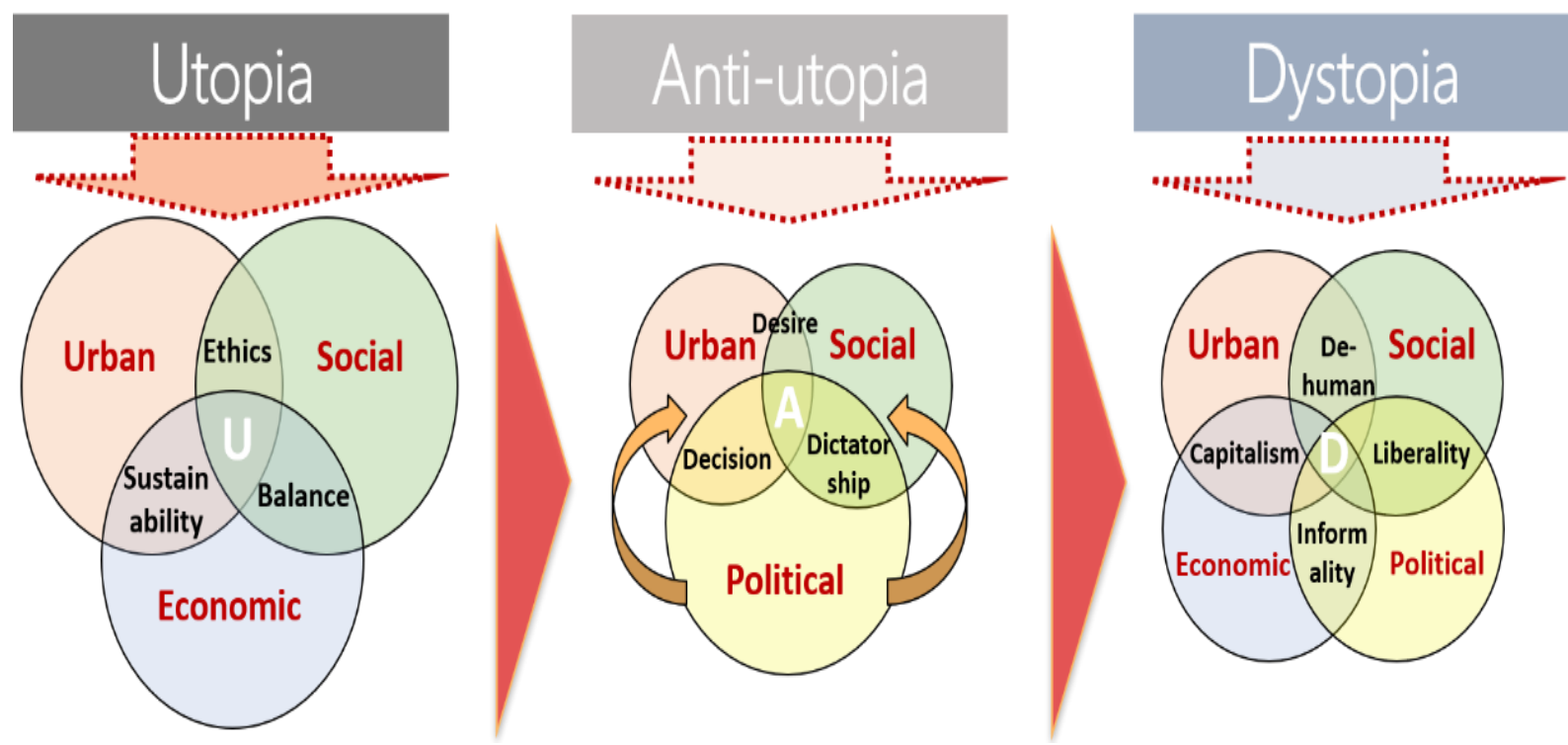

Figure (4): The types and relationships resulting from the change of factors, conditions, and policies followed - Source: Researchers, 2020

Along the past ten years, a clear human tragedy emerged on the level of local urban communities in spontaneous Egyptian cities, affecting the entire city and its associated communities. These factors led to an actual change in the conditions of most of the spontaneous Egyptian cities in terms of community development and design and other crucial issues that attacked the Egyptian urban environment with different impacts. This is because a group of people operates in various teams or on one side independently. These groups are all working in their favor, but they do not help to promote the urban truth, which ultimately contributes to the turning of cities into dystopia. 


\section{METHODS, DATA AND ANALYSIS:}

\subsection{Research Design}

Research Justifications: Content analysis searching for the Spontaneous Cities -Sites, as in (Figure 5).

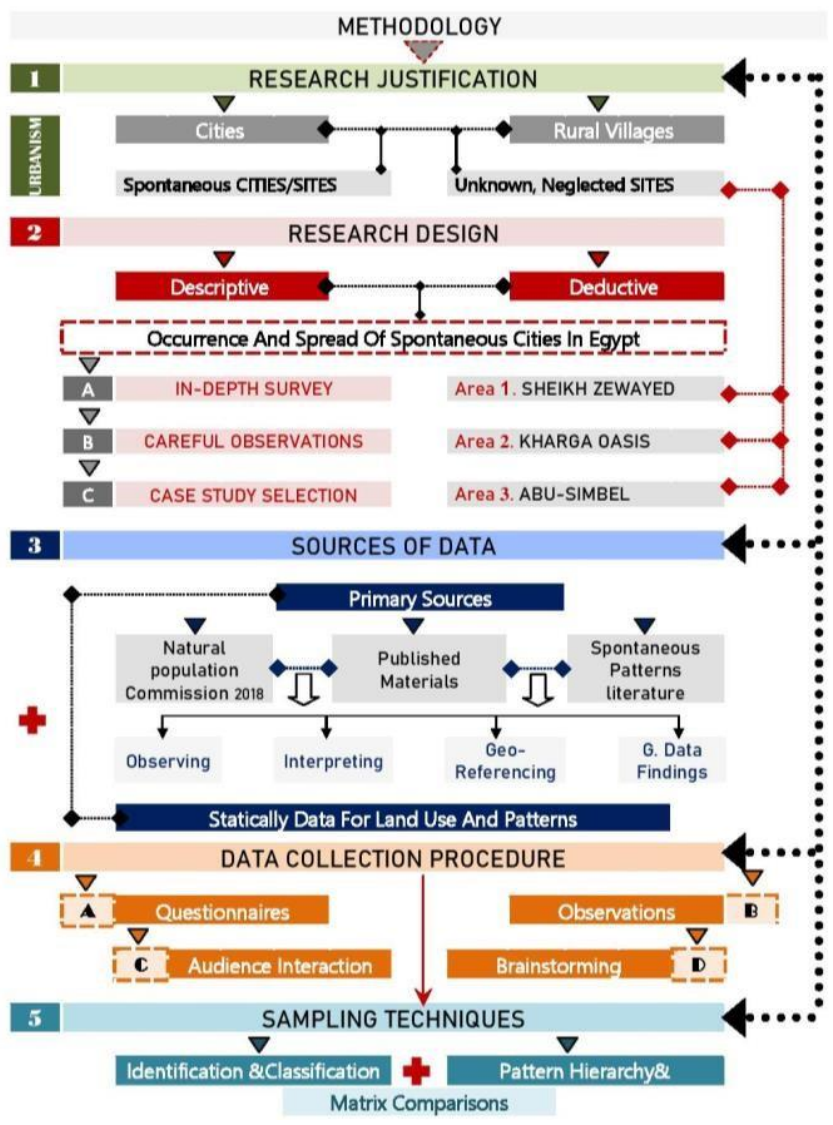

The adopted approach by this analysis is essentially descriptive and nonexperimental. The descriptive methodology is used to offer a concise description of the prevalence of spontaneous settlements in the outskirts of Egypt's urbanism to provide a comprehensive explanation of the obstacles to their survival and existence. This includes a detailed survey and a close evaluation of the behaviors of spontaneous cities, along with other urban planning practices. The focus of the research is on selected Egyptian spontaneous cities, namely Abu-Simbel, SheikhZuweid, and Kharja Oasis. Data from primary source are obtained through primary data including, open sources like, the National Population and Housing Census 2018 report, in addition to scientific research, studies, and several other related books in the field of spontaneous settlements. Finally, public surveys are distributed by oneon-one interaction with the resident of these settlements. 


\section{THE STUDY AREA}

\subsection{Definition of the Study Area}

According to the previous methodologies, the studies on Abu-Simbel, SheikhZuweid, and Kharja Oasis urban area boundary were studied, including factors influencing spontaneous planning conditions and influencing them (See Figure 6).
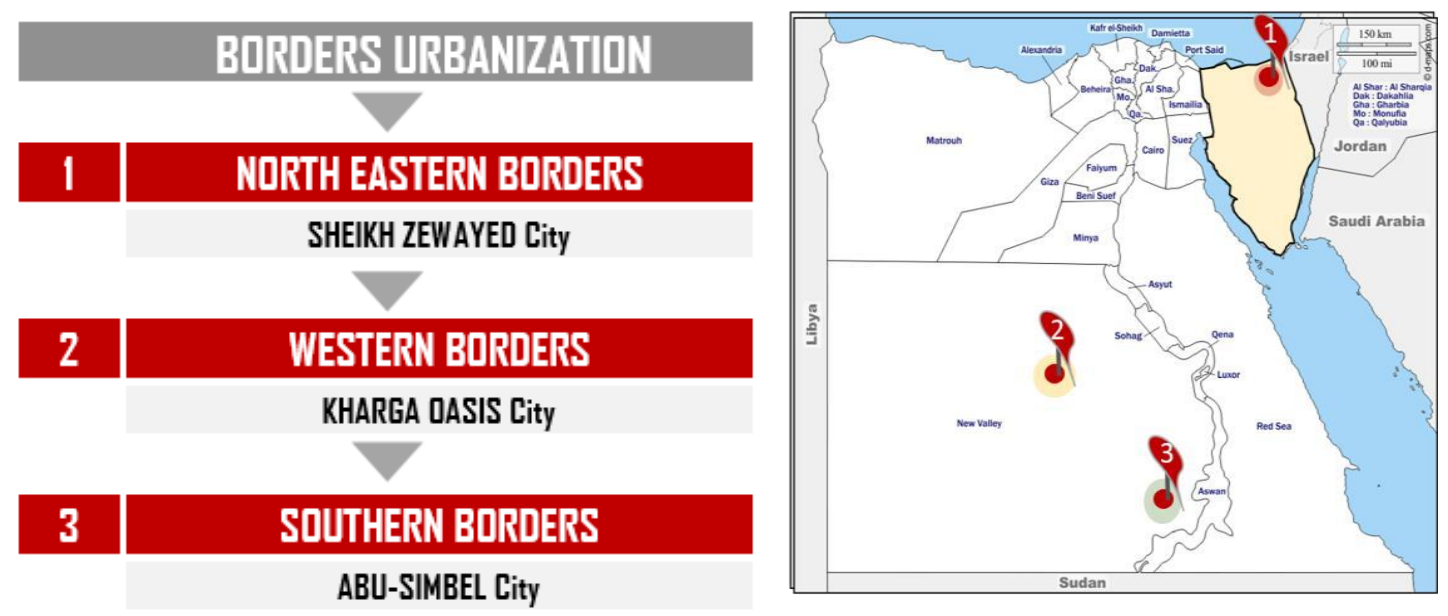

Figure (6): The selected case studies in Borders Urbanization in Egypt - Source: www.marefa.org/ By Researchers, 2020

The following are listed: the cultural, social, as well as urban factors that are taken into consideration. These factors represent a key to the origin and survival of all human communities, in addition to assessing the existing spontaneous urban structure in each city, versus the recommended proposals that are supposed to be correction to the faults associated with the current spontaneous citizen planning. The paper refers also to the reasons, which led to the advent and origin of the 3 Egyptian samples' styles of this type of planning.

\subsubsection{Area 1: (Sheikh-Zuweid) urban planning}

\section{- Characteristics:}

Geography: the city lies about $15 \mathrm{~km}$ far from the eastern borders, $2 \mathrm{~km}$ far from the Mediterranean shore and has a big water reservoir beneath. In 2006, population was estimated by about 18577 people and it is expected to reach 42200 people in 2027 with a rate of increase $3.99 \%$ with about 4014 families. 
Urban: the urban mass is concentrated in the center with scattered areas in all directions including 6 informal areas.

Urban Fabric Analysis: grid pattern in the east (Al Qawthar district), linear pattern in most areas, spontaneous pattern in the south and the edges, and the city consists of 3 main areas (Al Qawthar, Al Zohor and city center).

- $\quad$ Planning Motivations: The urban block of the city is not coherent. The proliferation of industrial and crafts areas without specifying a suitable location for them. There is a lack of vital uses around which buildings are built. Some roads are narrow and winding. There is a spread of random areas and a rise in its ratio compared to the ratio of urban mass. The presence of sand dunes to the north leads to sand crawling over the city, and the International Road divides the city.

- Geographic Location: This indicates to the current situation of spontaneous planning by the citizens and the proposed plan in the city`s strategic plan report (See Figure 7).

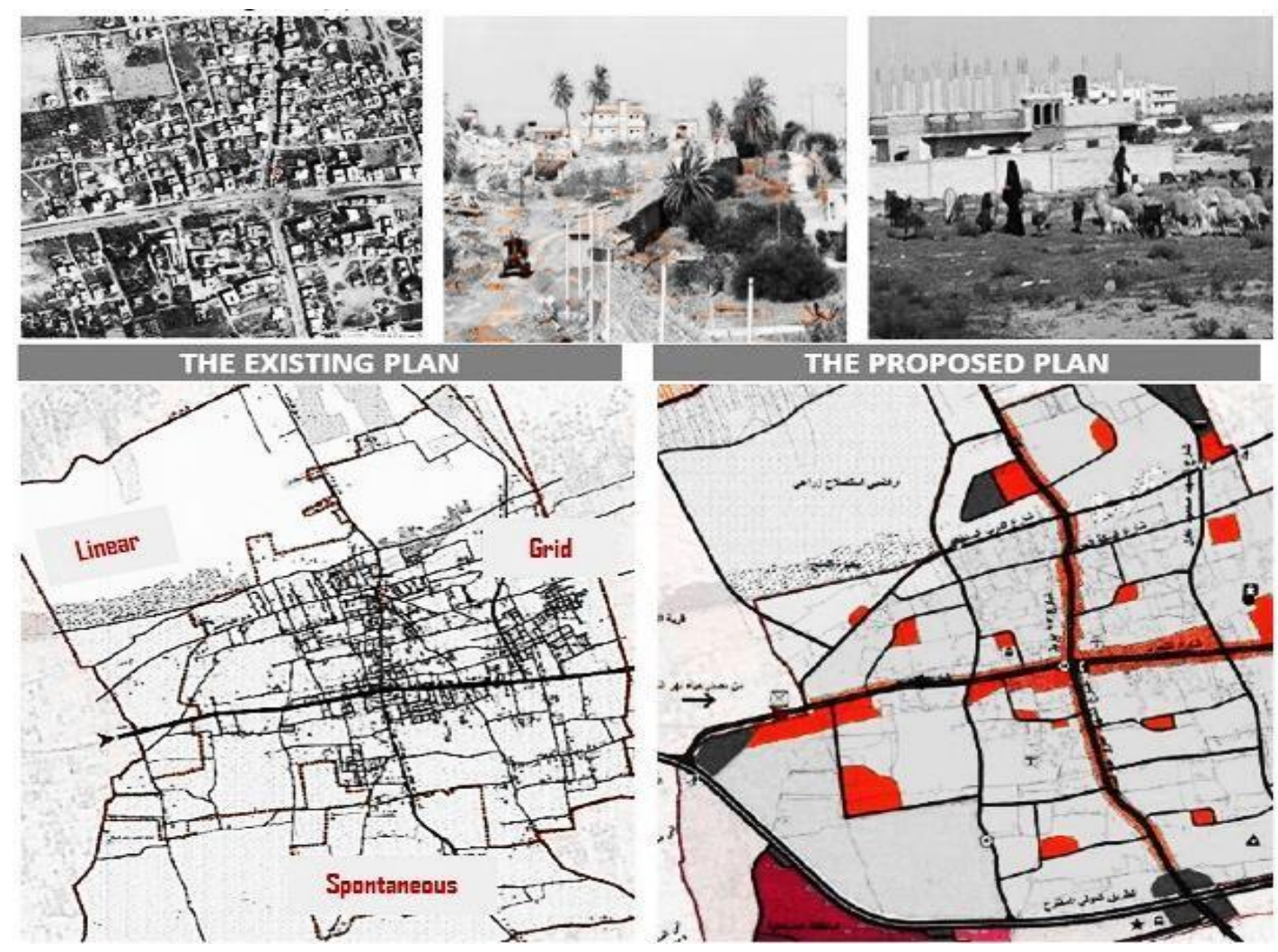

Figure (7): The Urban Plan and Photos of Sheikh-Zuweid - Source: SheikhZuweid Strategic plan Report, 2018/ Researchers, 2020 


\subsubsection{Area 2: (Kharja Oasis) Urban Planning}

\section{- Characteristics:}

Geography: The city lies in the south-western desert within a big desert depression and is associated with the presence of rocky ledges and sand dunes that affect the visual composition of the city's elements. In 2009, population was estimated by about 64349 people and it is expected to reach 92720 in 2027 with a rate of increase $2.05 \%$ with about $81 \%$ of the oasis.

Urban: The urbanization of the city is characterized by the interaction of various activities with the main uses.

Urban Fabric Analysis: The urban mass is divided into the old district, which lies on the eastern part of the regional road, with heritage buildings. It suffers from lack of services, and new extension areas that are modern areas dominated by the structural system.

- $\quad$ Planning Motivations: The abundance of lands designated for development, especially in the west of the city. One of the motivations is the existence of sand dunes crawl over the city in addition to preserving the distinctive urban desert heritage of the oasis. Among the motivations is the presence of many palm areas that permeate the urban mass and its outskirts, which are appropriate for the desert nature. Another motif is the climatic influences and the shift from the coherent pattern to the traditional urban style.

- Geographic Location: This indicates to the current situation of spontaneous planning by the citizens and the proposed plan in the city`s strategic plan report (See Figure 8) and (Table 2).
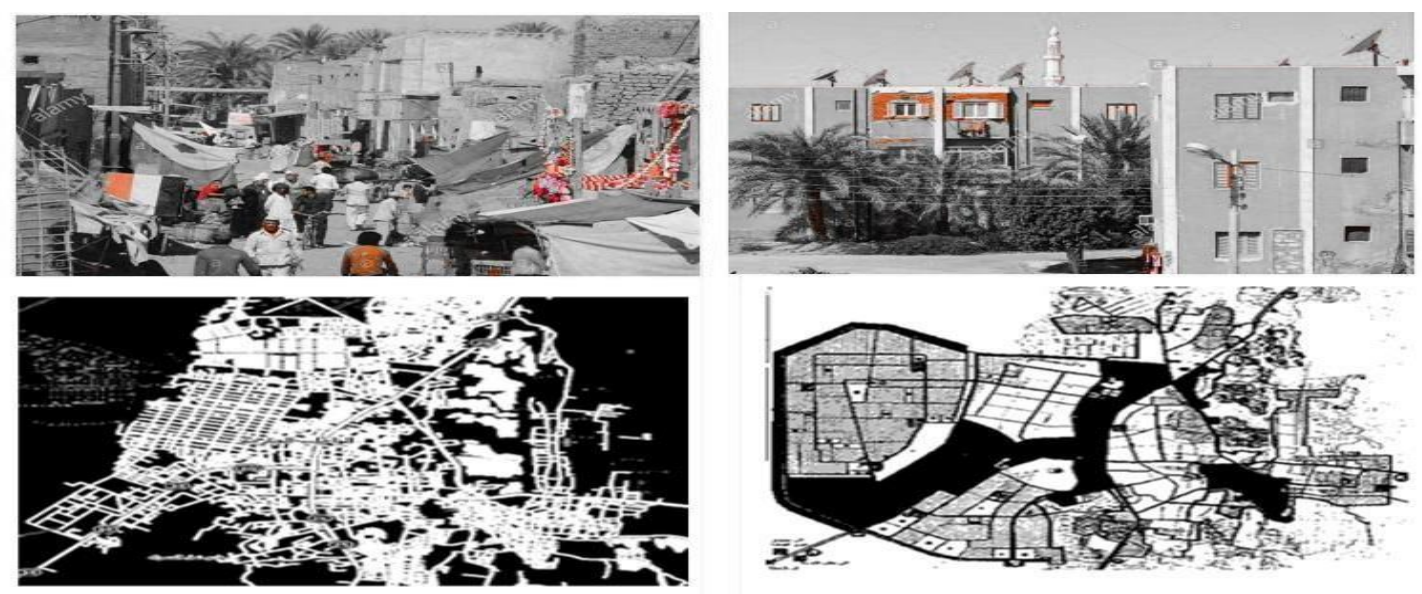

Figure (8): The urban plan and Photos of Kharja Oasis - Source: Kharja Oasis city Strategic plan Report, November .2018/ Researchers, 2020 
Table (2): A comparison of OLD and MODERN urban style of Kharga Oasis - Source: Kharja Oasis City Strategic Plan Report, November 2018/ Researchers, 2020

For the Old Urban Style
The old dwellings were constructed adjacent (a
compact urban form), and these dwellings are reached
by roofed lanes in most of their parts, with overhead
residential spaces.
The dwellings were designed to deal with the desert
environment, as evidenced by the few open walls, the
presence of internal courtyards, and many bends and
protrusions.
The residence consists of one or two floors, and
construction is carried out using the load bearing
walls with large thick.
The dwellings have small openings above the primary
one, as the small upper opening creates hot air.

For the Modern Urban Style
Modern housing has undergone intrusive planning
that contradicts the desert environment and ignores
Spontaneous design and planning controls for the
residents which stemmed from their needs.
Replacing the family home by the apartment unit.
This housing unit consisted of 1,2 or 3 rooms, in
addition to a living room, kitchen and bathroom,
which are frequent examples in most of Egypt's cities.
Lighting and ventilating the voids by large openings
(shish and glass), overlooking the outside, and a wall
thickness of $12 \mathrm{~cm}$.
The facades of the buildings lacked aspects that help
in shading, which leads to the rapid transfer of heat
through them.

\subsubsection{Area 3: (Abu-Simbel) Urban Planning}

\section{- Characteristics:}

Geography: The city lies in the far south of Aswan on the shores of Lake Nasser, and it is considered a touristic center around Ramses II and Nefertari temples. The city is a rocky hell with slope edges (190-250 m) above sea level confronting group of islands, bays. In 2006, population was estimated by about 2535 people of about $1.05 \%$ of the governorate, with about $57 \%$ males and $43 \%$ females.

Urban: The city consists of the main urban mass of spread traditional constellations on Lake Nasser due to the availability of agriculture lands, in addition to the new urban settlements linear to the main road to Aswan. The Urban mass is about 497.7 acres and residential buildings represent about $90.7 \%$ in the following patterns:

A) New residents (1980-2006).

B) Mid residents (workers - newcomers), official (Economic housing) and civil (small scale - connected- low services).

- $\quad$ Planning Motivations: The abundance of lands designated for development, especially in the North and south of the city. One of the motivations is the existence of Lake Nasser along the city in addition to preserving the distinctive ancient Egyptian temples and monuments. Among the motivations is the presence of many palm areas that permeate the urban mass and its outskirts, which are appropriate for the desert nature. Another motif is the climatic influences and the shift from the coherent pattern to the modern urban style. 
- Geographic Location: This indicates to the current situation of spontaneous planning by the citizens and the proposed plan in the city`s strategic plan report (See Figure 9).
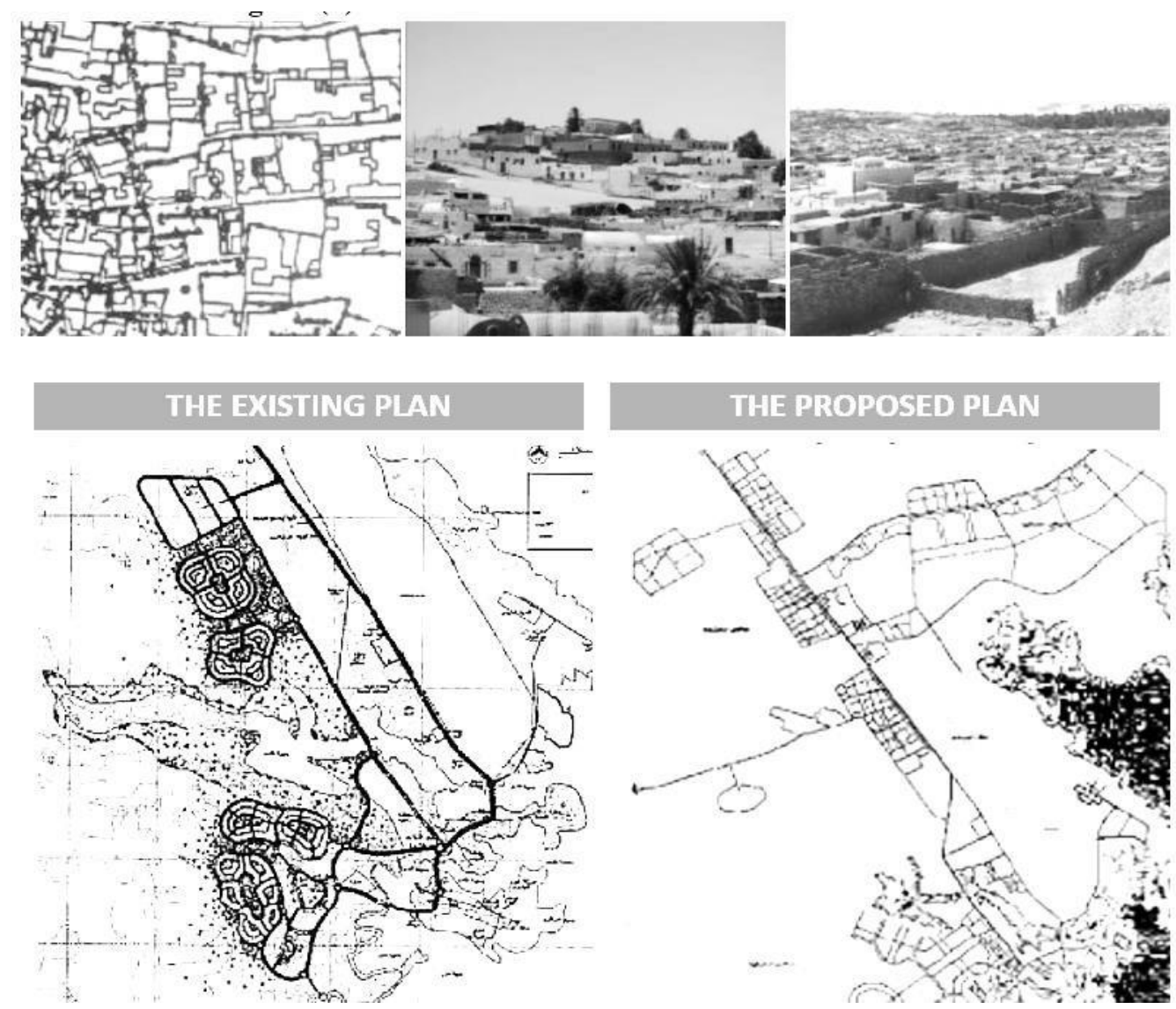

Figure (9): The Urban Plan and Photos of Abu-Simbel - Source: Abu-Simbel City Strategic Plan Report, 2018/ Researchers, 2020

\section{The Analysis of the 3 Case Studies Indicates the Following Facts:}

- In Area 1 (Sheikh-Zuweid), the main urban fabric is connected, spontaneous with some random constellations formed by the residents based on the natural and urban determinants in the area.

- In Area 2 (Kharja Oasis), the urban fabric is composite, represented in the traditional old style of the oasis (Compact fabric), in addition to the modern grid fabric in the west; as a result of the conflict between preserving cultural heritage, climatic conditions of the local environment and the desire to keep pace with technology and the use of cars and amenities.

- In Area 3 (Abu-Simbel), the urban fabric is linear due to the critical and highly sensitive Lake Nasser as a natural determinant of urban formation in the area, which made the 
urban growth happen in the form of separate urban communities facing the lake and connected by the same cultural traditions and customs.

\section{DISCUSSION OF FINDINGS}

By studying the distinctive characteristics of Utopia, Anti-Utopia, and Dystopia and classifying the basic aspects related to and component of each of them, it turns out that:

- $\quad$ The Utopia direction is composed of the urban, social and economic aspects and with the same interaction representing integration between the 3 main factors that guarantee the success of urbanism. This led to the creation of a set of inferred relationships represented in positive values such as sustainability, balance and ethics.

- The Anti-utopia direction is noticed as the political side dominates and overtakes the role of the community and the urban factor. This has led to a loss of balance in the urban development system based on the exchange of roles, and showed unstable terms like desire and dictatorship.

- $\quad$ The Dystopia direction is noticed in all social, urban, economic, and political aspects as they are present but overlapping roles and failure to define the responsibilities of each of them, which resulted in negative terms like de-humanization and informality.

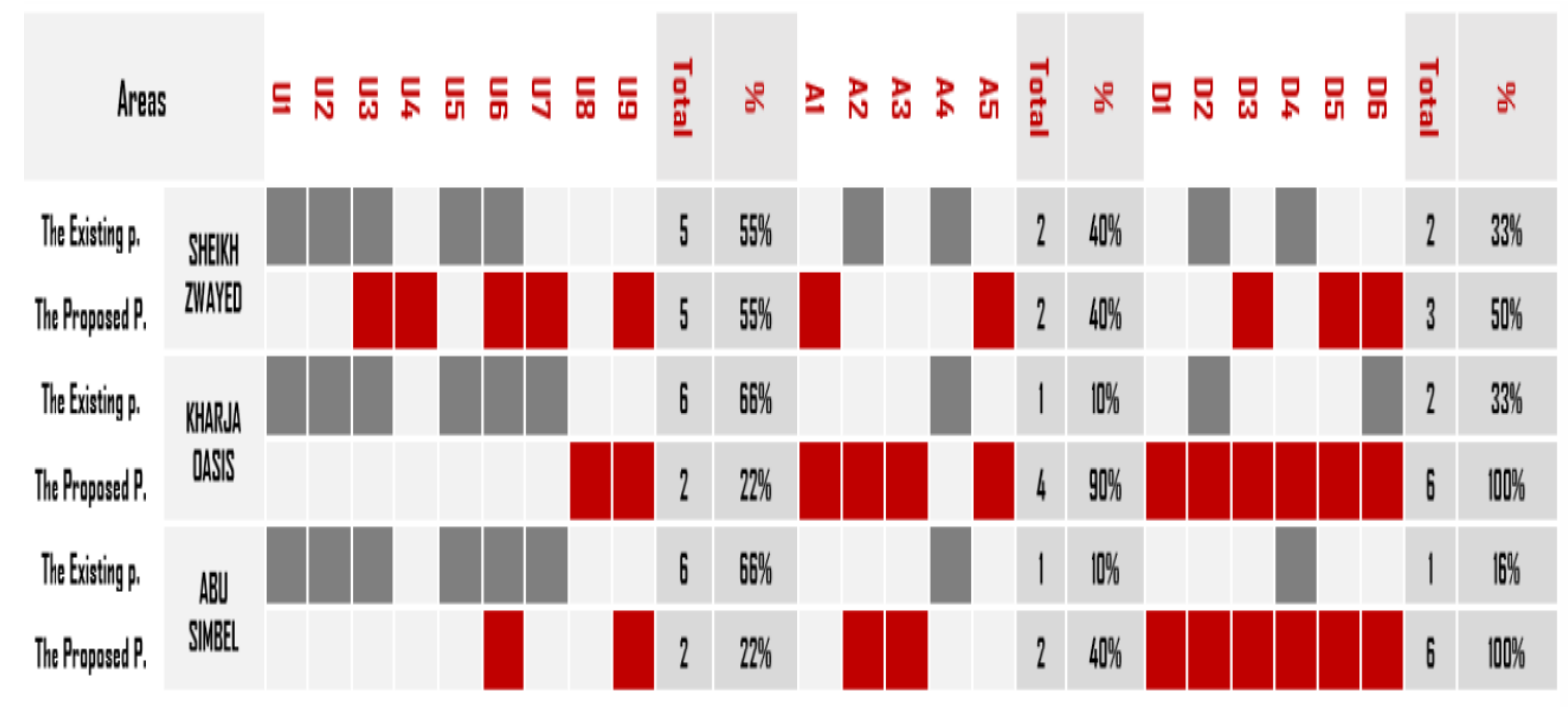

Fig. 10 - The analysis of case studies on the classifications and characteristics of each Utopia, Anti-Utopia, and Dystopia - Source: Researchers, 2020 
Based on the above and with matching the results of the analysis of case studies on the classifications and characteristics of each Utopia, Anti-Utopia, and Dystopia, the following is evident as in (Figure 10): first: referring to the existing plan in the 3 case studies as it is showing more Utopian evidence than Anti-Utopian and Dystopian because the social factor is the key engine behind the economic contributions in the urban form of the community; taking into consideration the difference in social structure, environmental and cultural differences. Second: referring to the proposed future and the following is noticed:

Area 1 (Sheikh-Zuweid): it shows more Utopian evidence more than Anti-Utopian and Dystopian. The proposed plan has taken into account and studied the needs of the population through community meetings, accordingly a set of alternatives was developed and evaluated, namely the central, linear and widespread distribution, and the third alternative was chosen, as it expresses the nature of the region despite the existence of some weaknesses in it.

- $\quad$ Area 2 (Kharja Oasis) and Area 3 (Abu-Simbel): the proposed plans show more evidence of Anti-Utopia and Dystopia more than Utopian which leads to the inapplicability of the previously unstable and negative terms found.

A detailed analysis based on highlighting the relation between spontaneous planning in the 3 case studies and the existence of Utopian, Anti-Utopian and Dystopian principles is necessary in order to enlighten urban planners, architects, residents and planning institutes and all terms concerned with the formation of human settlements in a city. This relation is critical to achieve a human, sustainable and successful planning, which relates to the roots of citizens, environment and culture of this city.

The following analysis represents location and projection. It compares the evidence of the principles of Utopia, Anti-utopia, and Dystopia on each area before and after urban development as shown in the existing plan and the proposed plan. (Figures 11, 12 and 13.(

It can be said that the case studies showed a positive model for balanced urban development based on the recognition and respect for the spontaneous fabric in the region through the proposed urban growth policies in Area 1 (Sheikh-Zuweid), while Area 2 (Kharja Oasis) and Area 3 (Abu-Simbel) represent an example of negative interaction with the local and traditional urban environment that we need to maintain, support, and continue its roots in place. This highlights the necessity of recognizing spontaneous urbanization as a type of "Counter planning" in Egypt. 
AREA I: (SHEIKH-ZUWEID) URBAN PLANNING
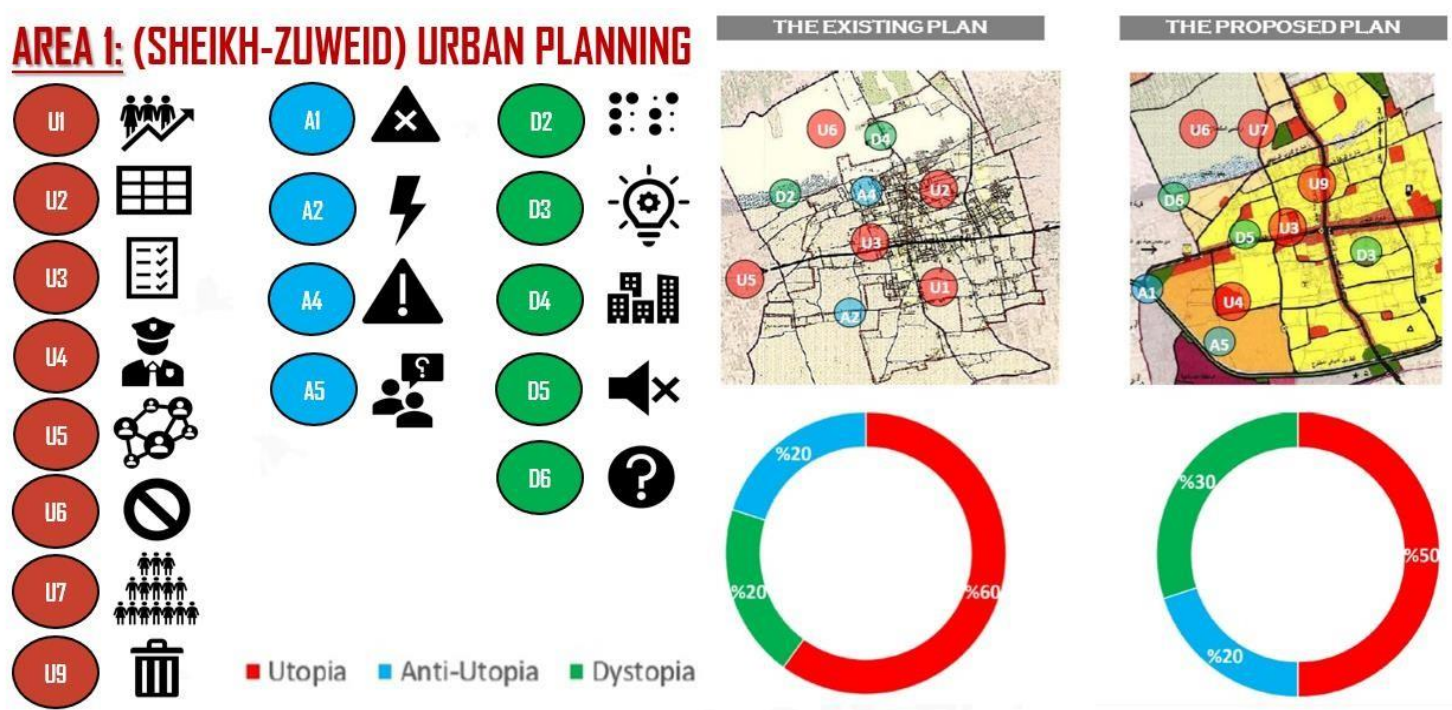

Figure (11): The analysis of Sheikh-Zuweid relations - Source: Researchers, 2020

AREA 2: (Kharja Dasis) URBAN PLANNING
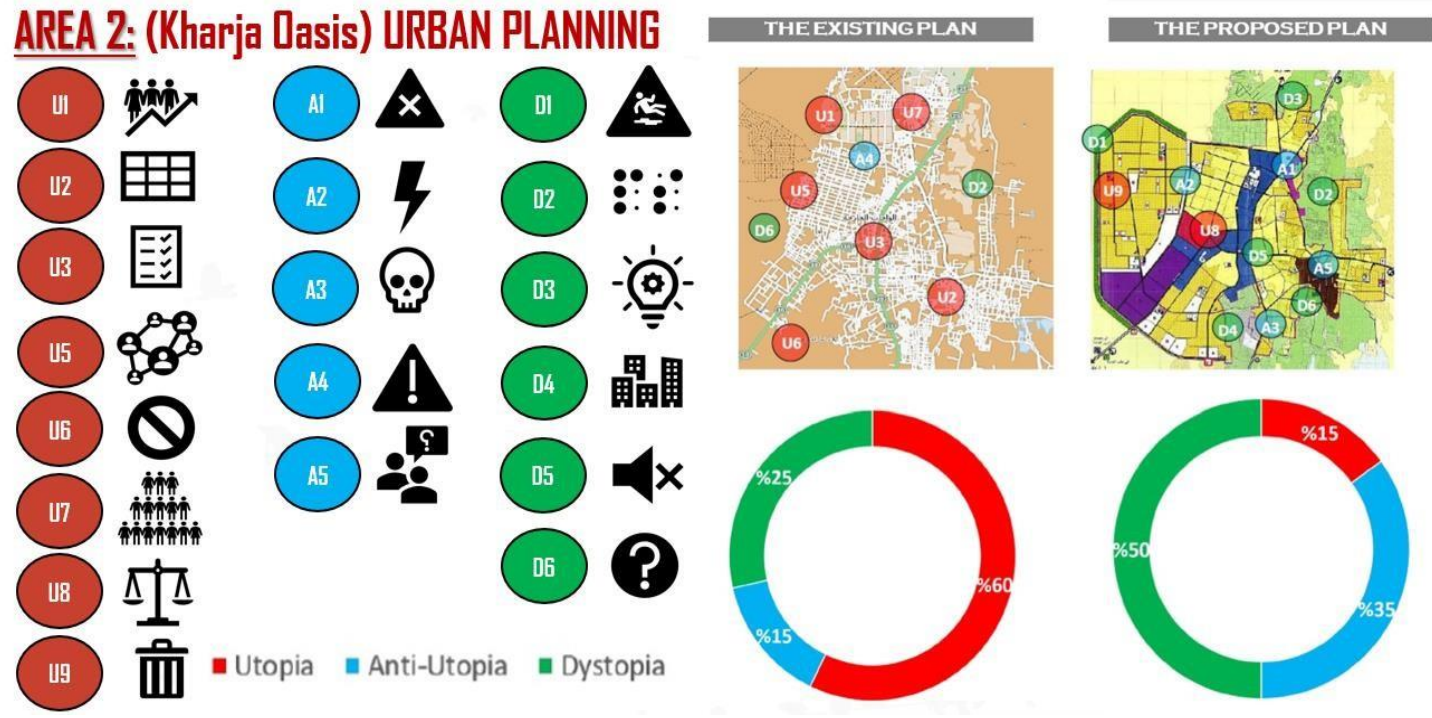

Figure (12): The analysis of Kharja Oasis relations - Source: Researchers, 2020 


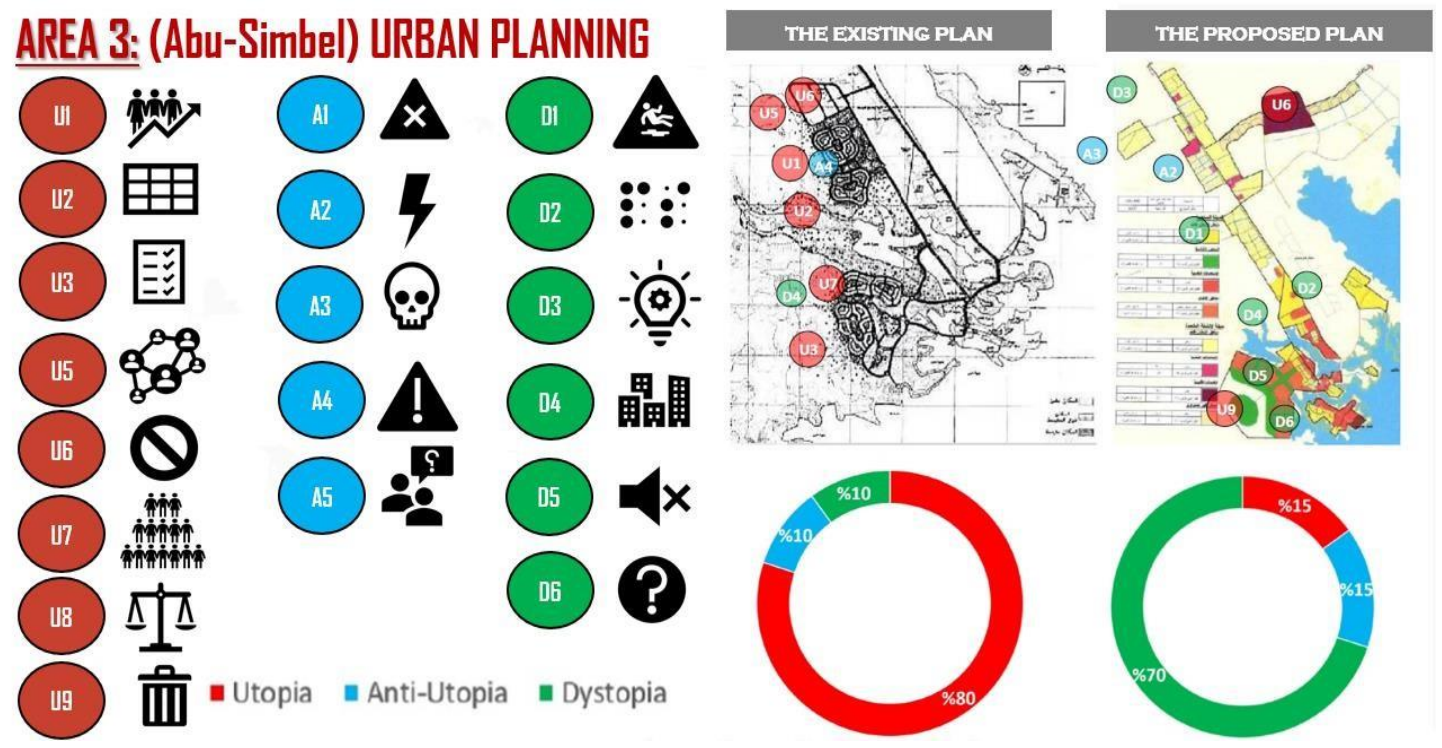

Figure (13): The analysis of Abu Simbel relations - Source: Researchers, 2020

\section{SUMMARY}

In urban planning the word 'spontaneous' suffers from some conventional understandings usually associated with vulnerability, and scarcity. Spontaneity is, thus, on the one hand a negative trait indicating free will and chaos, while on the other hand, it can be viewed as a positive trait, defined as an unpremeditated natural action, and therefore as a meaningful and sincere action. Spontaneity is then the transitional space between the laws, the mission, and potential realities as a place in which identity becomes apparent. Humanity represents its existence in the urban environment as an informal actor in spontaneous action. Spontaneous urbanization enhances the active role of local residents in developing their communities. Therefore, urban changes made by local residents to adopt with the real situation represent private and ideal spontaneous procedures taken to form the urban environment.

This manuscript is seen in principle as one of the efforts to stop the inappropriate urban transition that is taking place in the territory of Egyptian cities, particularly spontaneous urban areas. This reflects a rational step against construction plans, which should be taken seriously in order to ensure improved community life for residents. The future proposals for spontaneous cities should also emerge from the inside, not just to be in line with the 
existing cities, specifically in order to make them accessible to all and encourage the values of city rights and the feeling of belonging, and the most important thing is to accept that there are spontaneous cities, which are seldom researched by urban planners.

\section{CONCLUSION}

The study concludes that the "spontaneous cities" represent a kind of investment that can help transforming unplanned communities into livable cities, only if it is wellmanipulated. If legalized, the spontaneous cities can provide its residents with their needs. Previous studies prove that rejecting spontaneous cities, whether by neglecting or removing them, didn't solve the housing problem in Egypt. Therefore, it is necessary to follow more realistic policy that based on providing suitable and affordable alternatives. Spontaneous cities, as an urban type, should be recognized and accepted by the government as a real type that provides local residents with their housing needs. If encouraged and supported, residents of spontaneous cities can play a major role in developing and improving the real situation of their communities and this will be positively reflected on the entire society development. In other words, mutual positive reaction between the government and local residents of spontaneous cities will result in human development and eco-improvement.

\section{RECOMMENDATION}

The "spontaneous cities", as part of the urban structure in Egypt, should be reconsidered and should be accepted as a type of counter-planning that responds to the local residents' needs, customs, traditions and economic abilities that need to be improved by the government in a sustainable way.

From a scientific point of view, authorizing the "spontaneous cities" as a conception is vital for comprehensive planning. Therefore, it is recommended to conduct more advanced relevant research studies in this field. 


\section{References:}

Abdelllatif, M. (2003). Environmental compatibility in automatic architecture in Abu AlReish village housing in Aswan. Egypt: Faculty of Engineering, Assiut University.

Ashcroft, B. (2012). Introduction: Spaces of Utopia. Spaces of Utopia: An Electronic Journal, 2 (1), 1- 17.

Atkinson, P. (2005). Technology and the Vision of Utopia. Imagining the Future: Utopia, Dystopia and Science Fiction abstracts. Melbourne, Australia: Centre for Comparative Literature and Cultural Studies, Monash University, Clayton campus. Diambil kembali dari www.arts.monash.edu.au/lcl/conferences/utopias.

Balasopoulos, A. (2011). Anti-Utopia and Dystopia: Rethinking the Generic Field. An annual summer residency program organized by the Athens School of Fine Arts, Athens: School of Fine Arts, hal. 59-67.

Bernieri, M. L. (2019). A Journey through utopia (None Edition ed.). PM Press .

Blackshaw, N. (2014, April 16). Whose City is It Anyway? The Harsh Truth about Urbanisation. Diambil kembali dari 100resilientcities: https://www.theguardian.com/cities/2014/apr/16/whose-city-is- it-anyway-the-harshtruth-about-urbanisation

Choay, F., \& Bratton, D. (1997). The rule and the model: on the theory of architecture and urbanism.

Cambridge, Mass: MIT Press.

Clays, G. (2013, April). News from Somewhere: Enhanced Sociability and the Composite Definition of Utopia and Dystopia. History, The Journal of the Historical Association, 98(330), 145-173.

Cullen, G. (2015). The Concise Townscape by Gordon Cullen. London: Routledge.

Dabaieh, M. (2014). Energy efficient design strategies for contemporary vernacular Buildings in Egypt. Vernacular Heritage and Earthen Architecture: Contributions for Sustainable Development Correia, 599-604. Diambil kembali dari https://www.researchgate.net/publication/258121209_Energy_efficient_design_strategies for

_contemporary_vernacular_buildings_in_Egypt 
Ekandem, E., Daudu, P., Lamidi, R., Ayegba, M., \& Adekunle , A. (2014). Spontaneous Settlements: Roles and Challenges to Urban Planning. Journal of Sustainable Development Studies, 6(2), 361-390.

Ellin, N. (1999). Postmodern Urbanism. New York : Princeton Architectural Press.

Evans, P. (2002). Livable Cities? Urban Struggles for Livelihood and Sustainability. Berkeley: University of California Press.

Ferns, C. (1999). Narrating Utopia: Ideology, Gender, Form in Utopian Literature. Liverpool: Liverpool University Press.

Hayes, M. J., Kumar, S. P., \& Papadopoulos , M. D. (1987). RHYTHMIC ORGANIZATION OF SPONTANEOUS MOVEMENTS IN PREMATURE INFANTS $\leq 34$ WEEKS

GESTATIONAL AGE (GA). Pediatric Research, 181. doi:https://doi.org/10.1203/00006450- 198704010-00091

Jacobs , A., \& Appleyard, D. (2013). Toward an Urban Design Manifesto. Journal. of the American Planning Association, 53, 218-228.

Jacobs, J. (1992). The Death and Life of Great American Cities . Vintage; Reissue edition

Jameson, F. (2005 ). Archaeologies of the Future, The Desire Called Utopia and Other Science Fictions.

London: Ney York: Verso.

Jenks, M., \& Burgess, R. (2000). Compact Cities: Sustainable Urban Forms for Developing Countries.

London and New York: Spon Press.

Kazimee, B. (2008). Learning from vernacular architecture: sustainability and cultural conformity. WIT Transactions on Ecology and the Environment, 113.

Kellner, D. (2010). Ernst Bloch, Utopia and Ideology Critique. ZOMER, 44(21), 40-48.

Lenard, H. L. (1997). Principles for the Livable City. California, USA: International Making Cities Livable Conferences: Gondolier Press.

Levinson, D. M. (2017). Spontaneous Access Hardcover. network design lab. Diambil kembali dari https://core.ac.uk/reader/212694544 
Levitas, R. (2010). The Concept of Utopia. Bern: Peter Lang AG, International Academic Publisher. MacLeod , G., \& Ward, K. (2002). paces of Utopia and DYystopia: Landscape the Contemporary City.

Series B, Human Geography, 84(3/4), 53-170.

News from Somewhere: Enhanced Sociability and the Composite Definition of Utopia and Dystopia. (2013). The Journal of the Historical Association, 98 (330), 145-173.

planning, G. o. (2013). General strategic plan report for Sheikh zewayed city -North Sinai governorate.

General organization of urban planning.

SARGENT, L. T. (1994). The Three Faces of Utopianism Revisited. Utopian Studies, 5(1), 1 - 37. Sargent, L. T. (2010). Utopianism: A Very Short Introduction. England: OUP Oxford; Illustrated edition. The Principle of Hope. (1998). Minneapolis: Stanford University Press.

Urban Geography Glossary. (2021, April 20). Diambil kembali dari https://geographyfieldwork.com/:

https://geographyfieldwork.com/urban_geography_glossary.htm

Utopia in Dark Times: Optimism/ Pessimism and Utopia/Dystopia. (2003). Dalam R. LEVITAS, \& L. SARGISSON, Dark Horizons. Routledge.

Wiktionary. (2020, October 18). Diambil kembali dari Wiktionary: https://en.wiktionary.org/wiki/spontaneous

Received: April 2021

Accepted: June 2021 